\title{
Flora of Rambha Rural Municipality, Palpa, Nepal
}

\author{
Sushma Regmi and Umesh Koirala* \\ Department of Botany, Post Graduate Campus, T.U., Biratnagar, Nepal \\ "E-mail: umesh6977@hotmail.com
}

\begin{abstract}
The floristic study was conducted in Rambha Rural Municipality 1 Hungi, Palpa, Nepal to explore and document flowering plants. In this study, altogether 92 plant species were identified under 84 genera and 43 families. The study area was dominated by Lamiaceae (11 sps) followed by Leguminosae (10 sps), Euphorbiaceae (6 sps) and Anacardiaceae and Poaceae (5 sps each).
\end{abstract}

Key words: Dicotyledon, Flowering plants, Flora, Monocotyledon

\section{Introduction}

Flora is the name given to the collective plant life that grows or once grew in a certain area or during a given period of time. It usually refers to the native plant life present but does not include new species that have been introduced as well. A flora always contains scientific names, common names, descriptions, habitats, geographical distribution, illustrations, flowering times, and notes. Sometimes plants are listed alphabetically, and sometimes they are presented within classification system that indicates which are most similar or are thought to be related. Floras often also include devices called "keys" that enable the user to identify unknown plant.

Nepal presents a great diversity of flora and fauna to unique geographical location with representative of all major ecosystems. The country is rich in the vegetations having about 7000 species of flowering plants with $2.82 \%$ of higher plants and $4.5 \%$ of lower plants species of the world (Jha, 1992). Among them 315 species recognized to be endemic (Hara et al., 1978). More than 1000 species of wild plants are of medicinal value (Chaudhary, 1998). The country stands $27^{\text {th }}$ in the world and $10^{\text {th }}$ position in Asia in richness of flowering plants (Groombridge \& Jenkins, 2000). Hara et al. (1978) estimated that Nepal comprises 6500 species of flowering plants. Based on various publications, 6653 species of flowering plants have been reported so far (Kunwar \& Shrestha, 2009).

The top 10 largest families of flowering plants in Nepal are: Compositae (111 genera, 395 species), Graminae (113 genera, 366 species), Orchidaceae (91 genera, 324 species), Leguminosae (91 genera, 304 species), Rosaceae (29 genera, 192 species), Cyperaceae (21 genera, 191 species), Scrophulariaceae (39 genera, 167 species), Labiatae (48 genera, 150 species), Ranunculaceae (20 genera, 143 species) and Umbelliferae (44 genera, 123 species). Although the Government of Nepal has established 12 National Parks, 1 Wildlife Reserves, 1 Hunting Reserve, 6 Conservation Areas and 12 Buffer Zones covering 23.23\% of country's land area, its effective management is needed to address growing challenges.

The Flora of Nepal is the comprehensive record of all vascular plants of Nepal. It includes keys and descriptions to aid identification, distribution maps to assess rarity and 
geographical spread, authorities scientific names to promote communication, synonyms to help interpret previous works and supplementary information such as ecology, phenology, ethnobotanical uses and discussion on taxonomic issues.

Although Nepal has high species diversity, the level of endemism is not particularly high. Opinions vary on the numbers of strict endemics to Nepal, with estimates ranging from 246 to 342 species, or 4 to $5 \%$ of vascular plants. The low level of endemism is a reflection of Nepal's political borders and the diverse phytogeographic regions they span; if neighbouring areas were included then a considerable number of 'near endemics' could be added. There are many examples of primarily Nepalese species whose distributions extend just over the eastern borders into Sikkim, such as Chrysosplenium singalilense, Rodgersia nepalensisn and Rubus griffithii, and there are similar examples for the northern and western borders.

\section{Materials and Methods}

A herbarium is a collection of plant specimens that usually have been dried and pressed are arranged in the sequence of an accepted classification and are available for reference or other scientific study. Mostly this preservation includes drying and pressing of the plant material. Certain plants, which are either succulent or otherwise unsuitable for pressing and drying technique, may be fixed in suitable liquid preservations such as formaldehyde (25\%), acetic alcohol or FAA (5:5:90). Herbarium techniques involve: (i) Collection (ii) drying and pressing (iii) Poisoning (iv) Mounting (v) Stitching (vi) Labelling and (vii) Depositing.

Equipments for herbarium technique: 1) Plant press, 2) Field note book, 3) Vasculum, 4) Digger, 5) Secater and pruning shears, 6) collecting bags, 7) liquid preservation, 8) hand lens, 9) Waxed paper, 10) maps, 11) color charts, 12) Camera and films, and 13) Other field equipment such as altimeter, compass, pocket knife, soft lead pencils, insect repellant, portable plant drier and seed envelopes.

(i) Collection: Collections of plant material for herbarium were done using aesthetic sense and scientific mind. The angiospermic plant specimens were collected from Rambha rural municipality 1 No. Ward and areas of Palpa district. And collection was done by making field visit during flowering season. Plant specimens with fully grown leaves, complete inflorescence, flowers and fruits were collected as far as possible, along with necessary data i.e. habit, habitat, localities, colour of flowers, date of collection, date of flowering and fruiting and other taxonomic characters were noted. Meanwhile tagging was done and also the common name and their uses were noted if any. These information thus gathered were recorded in the field notebook.

(ii) Drying and pressing: The numbered collection were then be pressed in ordinary absorbent or newspaper folders. The main objective of pressing was to flatten and dry the specimen. During drying, specimens were stretched carefully between newspapers and pressed in the light wooden field press. These were dried with daily change of drying sheet for 6-10 days. Herbaceous specimens were washed to remove mud from roots. Other parts like leaves, flowers etc will spread out neatly. Leaves were folded facing both dorsally as well as ventrally. Longer specimens were folded in the pattern of "V", "U", "C" and "S". 
(iii) Poisoning: When the specimens were partially dehydrated, need poisoning to keep away from insects and fungal pests, using chemicals such as corrosive sublimate $\left(\mathrm{HgCl}_{2}\right)$ or any other suitable poisons. The specimens were again dried and kept ready for mounting.

(iv) Mounting: The dehydrated and well-pressed specimens were used for the preparation of herbarium specimens by using standard technique (Lawrence, 1951; Jain \& Rao, 1976). Mounting specimens is a phage of specimen preparation that has been developed from a number of different approaches. First the dried specimens were mounted on sheet of standard size herbarium paper (i.e., $42 \times 29 \mathrm{~cm}$ )

(v) Stitching: Dried specimens were glued and stitched on herbarium sheet made up to thick card sheet and cut to the required size $(42 \times 29 \mathrm{~cm})$.

(vi) Labelling: The field data were then entered on the right hand side lower corner of the herbarium sheet. These sheets were now ready for further scrutiny.

\section{Identification (Taxonomic information):}

The specimens were critically studied and identified with the help of standard literature. The standard table of Hutchinson was used for identifying families, and "Key to the genera in Nepal" part-I and II (1967-1968) were used for identifying genera. And other that were used for identification were that of Hains (1961), Collett (1971), Hooker (1872-1897), Hara et al $(1978,1982)$ and Siwakoti and Verma (1995). Identification of most of the specimens was done with the help of Prof. Dr. Sasinath Jha. The specimens were deposited at the Herbarium section of Botany Department, Post Graduate Campus, Biratnagar.

\section{Presentation}

Family are arranged alphabetically and for description of genera and species, the modified Engler system has been followed as in the 'Flora of China'. Dichotomous keys have been prepared to genera and species for the families which contain more than one genus and for the genera which contain more than one species, respectively. Species were cited using latest taxonomic literature. The basionyms and synonyms are also given whenever possible which must be accepted for synonyms. The local name was obtained from field note or from secondary literature

\section{Results}

From the study area altogether 92 species under 84 genera and 43 families were identified. The dominant families of the study area are Lamiaceae with 11 species, Leguminosae with 10 species, Euphorbaceae with 6 species, Anacardiaceae and Poaceae with 5 species and Acanthaceae and Compositae with 4 species.

Families with 3 species are Asteraceae, Combretaceae, Rosaceae and Verbanaceae. Asclepiadaceae, Lythraceae, Myrtaceae and Verbenaceae are the family with 2 species. Family with only one genera are Aceraceae, Agavaceae, Amaranthaceae, Annonaceae, Apocynaceae, Bombaceae, Cannabaceae, Chenopodiaceae, Convolvulaceae, Crassulaceae, Dipterocarpaceae, Hypoxidaceae, Juglandaceae, Liliaceae, Malvaceae, Melastomaceae, Meliaceae, Menispermaceae, Oleaceae, Orobanchaceae, Oxalidaxeae, Polygonaceae, Ranunculaceae, Sapotaceae, Solanaceae, Scrophulariaceae, Theaceae and Ulmaceae. Among all of the 92 species, trees are dominant in the species composition attaining $33.69 \%$ of the total floristic value. After that comes shrubs with $27.17 \%$, herbs with $25 \%$, 
then climber with $7.6 \%$ and under shrubs with $6.52 \%$. Dicotyledons are 86 in number comprising $93.48 \%$ and monocotyledons are 6 in number comprising $6.52 \%$. Dicotyledons are dominant over monocotyledons.

Table 1. List of the families represented in the study area with respective number of their genera and species

\begin{tabular}{|c|c|c|c|}
\hline S.N. & Families & No. of Genera & No. of Species \\
\hline 1. & Acanthaceae & 4 & 4 \\
\hline 2. & Aceraceae & 1 & 1 \\
\hline 3. & Agavaceae & 1 & 1 \\
\hline 4. & Amaranthaceae & 1 & 1 \\
\hline 5. & Anacardiaceae & 4 & 5 \\
\hline 6. & Annonaceae & 1 & 1 \\
\hline 7. & Apocnaceae & 1 & 1 \\
\hline 8. & Asclepiadaceae & 2 & 2 \\
\hline 9. & Asteraceae & 3 & 3 \\
\hline 10. & Bombaceae & 1 & 1 \\
\hline 11. & Cannabaceae & 1 & 1 \\
\hline 12. & Chenopodiaceae & 1 & 1 \\
\hline 13. & Combretaceae & 2 & 3 \\
\hline 14. & Compositae & 3 & 4 \\
\hline 15. & Convolvulaceae & 1 & 1 \\
\hline 16. & Crassulaceae & 1 & 1 \\
\hline 17. & Dipterocaroaceae & 1 & 1 \\
\hline 18. & Euphorbiaceae & 6 & 6 \\
\hline 19. & Hypoxidaceae & 1 & 1 \\
\hline 20. & Juglandaceae & 1 & 1 \\
\hline 21. & Lamiaceae & 9 & 11 \\
\hline 22. & Leguminosae & 8 & 10 \\
\hline 23. & Liliceae & 1 & 1 \\
\hline 24. & Lythraceae & 2 & 2 \\
\hline 25. & Malvaceae & 1 & 1 \\
\hline 26. & Melastomaceae & 1 & 1 \\
\hline 27. & Meliaceae & 1 & 1 \\
\hline 28. & Menispermaceae & 1 & 1 \\
\hline 29. & Myrtaceae & 1 & 2 \\
\hline 30. & Oleaceae & 1 & 1 \\
\hline 31. & Orobanchaceae & 1 & 1 \\
\hline 32. & Oxalidaceae & 1 & 1 \\
\hline 33. & Poaceae & 5 & 5 \\
\hline 34. & Polygonaceae & 1 & 1 \\
\hline 35. & Ranunculaceae & 1 & 1 \\
\hline 36. & Rosaceae & 3 & 3 \\
\hline 37. & Sapotaceae & 1 & 1 \\
\hline 38. & Solanaceae & 1 & 1 \\
\hline 39. & Scrophulariaceae & 1 & 1 \\
\hline 40. & Theaceae & 1 & 1 \\
\hline 41. & Ulmaceae & 1 & 1 \\
\hline 42. & Vitaceae & 2 & 2 \\
\hline 43. & Verbenaceae & 3 & 3 \\
\hline
\end{tabular}


Table 2. Number and percentage of the plant species on the basis of their life form.

\begin{tabular}{clcc}
\hline S.N. & Life form(Habit) & Total Number & Percentage (\%) \\
\hline 1 & Tree & 31 & 33.69 \\
2 & Shrub & 25 & 27.17 \\
3 & Herb & 23 & 25 \\
4 & Climber & 7 & 7.60 \\
5 & Under shrub & 6 & 6.52 \\
\hline
\end{tabular}

By the observation of above table, trees are dominant in species composition, attaining $33.69 \%$ of the whole floristic value. After that come shrubs with $27.17 \%$, herbs with $25 \%$, climber with $7.60 \%$ and under shrubs attaining $6.52 \%$.

Table 3. Ratio of family to genera, genera to secies and family to species.

\begin{tabular}{cccc}
\hline Family : Genera & Genera : Species & Family : Species \\
\cline { 1 - 1 } & $1: 1.95$ & & $1: 2.13$ \\
\hline
\end{tabular}

Above table shows that the ratio of family to genera is $1: 1.95$, ratio of genera to species is 1:1.09 and the ratio of family to species 1:2.13.

Table 4. Number, percentage and ratio of dicotyledon and monocotyledon species.

\begin{tabular}{lcccc}
\hline & Number & Percentage (\%) & & Ratio \\
\cline { 1 - 3 } \cline { 5 - 5 } Dicotyledons & 86 & 93.48 & & Monocot : Dicot \\
Monocotyledons & 6 & 6.52 & & $1: 14.33$ \\
\hline
\end{tabular}

Visualizing the above result, dicotyledons are 86 in number comprising $93.48 \%$ and monocotyledons are 6 in number comprising 6.52\%. Dicotyledons are dominant over monocotyledons

\section{Discussion}

The present floristic work is completed with finding of altogether 92 plant species, belonging to 84 genera and 43 families. Out of 92 species 86 plant species are found to be dicotyledons and 6 plant species are found to be monocotyledons.

Among 92 plant species, 31 species are trees, 25 species shrubs, 23 are herbs, 7 of the species are climbers and 6 of them are undershurbs. So, in the study area, trees are dominant in comparison to shrubs, herbs, climbers and under shrubs.

Out of all 43 families, the dominant family in the study area is Lamiaceae with 11 plant species followed by Leguminosae and Euphorbiaceae with 10 and 6 families. The families with 5 species are Anacardiaceae and Poaceae. Acanthaceae and Compositae are the family with 4 species and Asteraceae, Combretaceae, Rosaceae and Verbenaceae are the families with 3 species. Asclepiadaceae, Lythraceae, Myrtaceae and Vitaceae are the families with 2 species. The monospecific families are Aceraceae, Agavaceae, Amaranthaceae, Annonaceae, Apocynaceae, Bombaceae, Cannabaceae, Chenopodiaceae, Convolvulaceae, Crassulaceae, Dipterocarpaceae, Hypoxidaceae, Juglandaceae, Liliaceae, Malvaceae, Melastomaceae, Meliaceae, Menispermaceae, Oleaceae, Orobanchaceae, Oxalidaceae, Polygonaceae, Ranunculaceae, Sapotaceae, Solanaceae, Scrophulariaceae, Theaceae and Ulmaceae. 
The most dominant plant species in the study area are: Adhatoda vasica, Artemisia Dubia, Bauhinia vahlii, Dalbergia sissoo, Pyrus pashia, Rubus ellipticus, Schima wallichii, Shorea robusta, Syzigium cumini, Terminalia alata, etc

Out of 92 species more than 30 species are of medicinal value. Some of the collected plant species which are of medicinal importance are: Adhatoda vasica, Buddlegia asiatica, Rauvolfia serpentine, Rubus ellipticus, Woodfordia fruticosa, Morus alba, Colebrokea oppositifolia, Artimesia dubia, Eupatorium odoratum, Riccinus communis, Mallotus philippenis, Oxalis orniculata, Pyrus pashia etc.

Some of edible fruit species are: Rubus ellipticus, Phyllanthus emblica, Syzygium cumini, Morus alba, Prunus persica, etc. Shorea robusta, Dalbergia sisoo, Schima wallichii, Terminalia bellirica, Terminalia chebula etc are the collected plant species which are important economically

\section{References}

Chaudhary, R.P. 1998. Biodiversity in Nepal status and conservation. S. Devi, Saharanpur (V.P), India and Tecpress Books 487/42, Soiwattanasilp Pratunam, Bangkok 10400, Thailand.

Collett, H. 1971. Flora Simlensis ( $3^{\text {rd }}$ ed.). Bishen Singh, Mahendra Pal Singh, Dehra Dun, India.

Groomdridge, B. \& M.D. Jenkins 2000. Global biodiversity: Earth's living resources in the $21^{\text {st }}$ Century. World Conservation Press, Cambridge, UK.

Haines, H.H. 1961 (Revised ed.). The botany of Bihar and Orissa, vol. 3. Bishen Singh, Mahendra Pal Singh, Dehra Dun, India.

Hara, H. A.O. Chater \& L.H.J. Williams 1982. An enumeration of flowering plants of Nepal, vol 3. British Museum (Nat. Hist.), London.

Hara, H., W.T. Stearn \& L.H.J. Williams 1978. An enumeration of the flowering plants of Nepal, vol. 1. British Museum (Nat. Hist.), London.

Hooker, J.D. 1872-1897. The flora of British India, vol. 7. London.

Jain, S.K. \& R.R. Rao 1976. A handbook of fields and herbarium methods. Today and Tomorrow's Printer's and Publishers, Delhi.

Jha, P.K. 1992. Man and environment of Nepal (Ed. T.C. Majupuria). White Lotus Co. Ltd., Bangkok, Thailand.

Kunwar, R.M. \& K. Shrestha 2009. Taxonomic need assessment on floral biodiversities of Nepal. Final report submitted to GTI Nepal Chapter, Department of Plant Resources, Thapathali, Kathmandu.

Lawrence, G.H.M. 1951. Taxonomy of vascular plants. Macmillian Co., NY Press, J.R.

Siwakoti, M. \& S.K. Varma 1995. Convolvulaceae of the plains of eastern Nepal. In: Taxonomy and Biodiversity (Ed. A.K. Pandey). 